
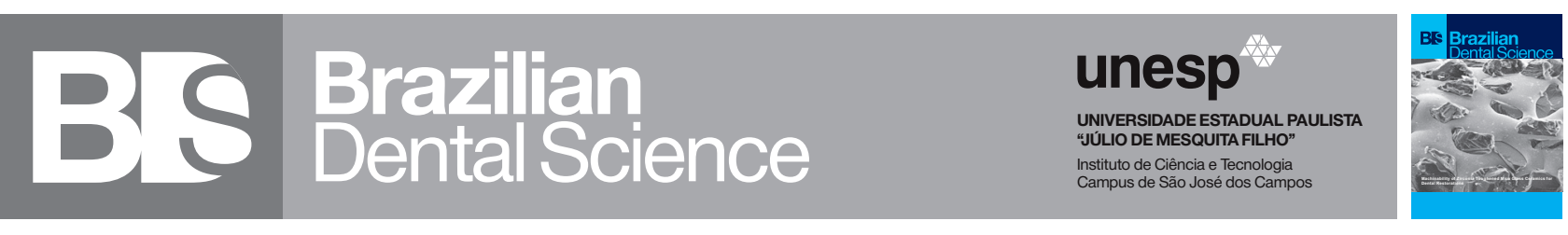

\title{
Differences of Salivary Ph, Feature, And Volume Of Children At Three Kindergartens With Different Socioeconomic Standard
}

Diferenças do Ph Salivar, Característica e Volume, de Crianças Em Três Jardins De Infância Com Diferentes Padrões Socioeconômicos

\author{
Anne Agustina SUWARGIANI ${ }^{1}$, Riana WARDANI ${ }^{1}$, Fidya Meditia PUTRI ${ }^{1}$, Tadeus Arufan JASRIN ${ }^{2}$, Inne Suherna SASMITA ${ }^{3}$ \\ 1 - Universitas Padjadjaran, Faculty of Dentistry, Department of Dental Public Health, Indonesia. \\ 2 - Universitas Padjadjaran, Faculty of Dentistry, Department of Oral Biology, Indonesia. \\ 3 - Universitas Padjadjaran, Faculty of Dentistry, Department of Pedodontics, Indonesia.
}

\section{ABSTRACT}

Introduction: Saliva is the most important biological factor to protect against dental caries. When saliva flow is reduced, oral health problems such as dental caries and oral infections can develop. It was suggested that the effect of low salivary $\mathrm{pH}$ is more in plaque close to the area of susceptible tooth surface. The presence of saliva in pre-school age children is a significant indicator in oral health assessment oral health. There has been an association between salivary cortisol and socioeconomic variable. Descriptions above have encouraged us to examine the salivary $\mathrm{pH}$, feature, and volume of pre-school-aged community. Thus, this study was aimed to describe the differences in salivary $\mathrm{pH}$, feature, and volume of the children in the three pre-school with different location and socioeconomics aspect. Methods: Descriptive survey, with a population of preschool students in 3 different kindergartens with different socioeconomic environment. Inclusion criteria were the pre-school-aged community and got permission from parents. Exclusion criteria were a pre-school-aged community under medication treatment causes hyposalivation or hypersalivation and children who did not want to be involved in the study, with total sampling as the sampling technique, resulted in as much a 101 respondents as the study sample. The saliva was collected with unstimulated technique. Data analysis was performed using relative frequency distribution. Results: The salivary $\mathrm{pH}$ was slightly higher in male children than female by

\section{RESUMO}

Introdução: A saliva é o fator biológico mais importante na proteção contra a cárie dentária. Quando o fluxo salivar é reduzido, podem ocorrer problemas na saúde bucal, como cáries e infecções orais. Foi sugerido que o efeito do baixo $\mathrm{pH}$ salivar é aumentado na placa, próxima à área de superfície dentária suscetível. A presença de saliva em crianças em idade pré-escolar é um indicador significativo na avaliação da saúde bucal. Houve associação entre cortisol salivar e variáveis socioeconômicas. As descrições acima nos encorajaram a examinar o $\mathrm{pH}$ salivar, características e volume da comunidade em idade pré-escolar. Assim, este estudo teve como objetivo descrever as diferenças de $\mathrm{pH}$, característica e volume salivar das crianças de três pré-escolas com localização e aspectos socioeconômicos distintos. Material e Métodos: Pesquisa descritiva, com população de estudantes da pré-escola de três diferentes jardins de infância com diferentes ambientes socioeconômicos. Os critérios de inclusão foram comunidade em idade pré-escolar e permissão dos pais. Os critérios de exclusão foram comunidade em idade pré-escolar sob tratamento medicamentoso que causa hipossalivação ou hipersalivação e também crianças que não quiseram se envolver no estudo, com amostragem total resultando em 101 entrevistados como a amostra do estudo. A saliva foi coletada com a técnica não estimulada. A análise dos dados foi realizada usando distribuição de frequência relativa. Resultados: O $\mathrm{pH}$ salivar foi ligeiramente superior nas crianças do sexo masculino do que no feminino em 0,1 . O 
0.1 . The average $\mathrm{pH}$ value was 7.25 . The salivary feature was mostly frothy bubbly, followed by thin and watery, and the sticky bubbly feature was found the least. The salivary volume of the pre-school-aged community was mostly in the very less category, followed by the less category, with no normal category was found. the p-values of salivary $\mathrm{pH}$ and salivary features were below 0.05 There are no significant differences between the salivary $\mathrm{pH}$ and salivary feature of children from the three studied kindergartens. However, there is a significant difference in the salivary volume found in children from kindergartens located in high socioeconomic standard and middle socioeconomic standard areas, which have a higher salivary volume than the children from kindergartens situated in areas with lower socioeconomic standard. Conclusion: since the reduced salivary volume was associated to children with lower socioeconomic standard, this association can justify the higher risk for caries described in the literature.

\section{KEYWORDS}

Salivary pH; Salivary feature; Salivary volume; Pre-school-aged children. valor médio do $\mathrm{pH}$ foi de 7,25 . O aspecto salivar era principalmente espumoso com bolhas, seguido de aspecto tênue e aguado, e o aspecto pegajoso e espumante foi o menos encontrado. Ovolume salivar dos estudantes em idade pré-escolar encontravase majoritariamente na categoria inferior a todas, seguida da categoria menos, não sendo encontrada nenhuma categoria normal, onde os valores de p do $\mathrm{pH}$ salivar e características salivares estavam abaixo de 0,05. Não há diferenças significativas entre o $\mathrm{pH}$ salivar e a característica salivar das crianças dos três diferentes jardins de infância estudados. No entanto, existe uma diferença significativa no volume salivar encontrado em crianças de creches localizadas em áreas de médio e alto padrão socioeconômico, que apresentaram maior volume salivar do que as crianças de creches situadas em áreas de menor padrão socioeconômico. Conclusão: $\mathrm{O}$ volume salivar reduzido esteve associado a crianças com menor padrão socioeconômico, logo essa associação pode justificar o maior risco de cárie descrito na literatura.

\section{PALAVRAS-CHAVE}

pH salivar; Característica salivar, Volume salivar; Pré-escolar.

\section{INTRODUCTION}

$\mathrm{D}$ ental caries is one of the most common oral diseases in humans and is a chronic health problem that continues to develop throughout the world. Caries usually occurs in children and adolescents and often causes tooth loss in a younger population, but can also occur in all age groups [1].

Dental caries is a disease that results from microbiome dysbiosis with the involvement of multiple cariogenic species, including mutans streptococci (MS), lactobacilli, Scardovia wiggsiae, and several Actinomyces species that have the cariogenic traits of acid production and acid tolerance. One of the primary functions of the saliva is its antimicrobial and cleansing activity, which able to degrades some bacterial cell walls and inhibiting their growth [2]. The process by which saliva dilutes and eliminates food substances such as sugars and acids from the oral cavity is referred to as salivary or oral clearance $[3,4]$. The clearance rate is determined by the salivary flow rate, the volumes of saliva in the mouth before and after swallowing and the swallowing frequency [5]. It has been shown that low residual volume of saliva and high unstimulated and stimulated salivary flow rates facilitate the rate of clearance of fermentable carbohydrates and acids from food and drinks [3].

Saliva also plays an essential role in the clearance of desquamated epithelial cells from the oral cavity, each of which carries about 100 microorganisms and for the elimination of the microorganisms present in saliva [6]. One milliliter of human saliva from a healthy individual contains about 100 million bacterial 
cells. With a normal salivary secretion of $750 \mathrm{ml}$ per day, about $8 \times 10^{10}$ bacteria are shed from the oral mucosal surfaces per day, equivalent to 5-10 $\mathrm{g}$ of the wet weight of bacterial cells [7]. By removing material that may serve as culture media, saliva inhibits the growth of bacteria through the lysozyme enzyme, which has the ability to lyse or dissolve, certain bacteria [8] Thus, saliva flow and subsequent swallowing promote the removal of a significant number of bacteria and thereby play an essential role in balancing oral microbiome dysbiosis.

Saliva is one of the main etiology of dental caries incidence, and particularly its average flow and fluoride content. Dental caries results from the dissolution of minerals from the tooth surface by organic acids formed from the bacterial fermentation of sugars. The capacity of saliva to flush microorganisms and substrates and maintain oral cleanliness may be influenced by its consistency and flow rate [3]. The average salivary flow is a very influential cleansing agent of food and snack retentions [9]. This condition, of course, is very dependable with the oral cavity condition. Also, saliva has been regarded as protective fluid against dental caries due to the buffering and antibacterial activity, and continuous supply of minerals, particularly calcium and inorganic phosphate [9].

The protective role of salivary factors such as salivary $\mathrm{pH}$, flow rate, and calcium, has been evaluated since the middle of the last century. Most of the previous studies showed that the salivary $\mathrm{pH}$ was significantly decreasing in subjects with dental caries, indicating a favorable environment for the process of demineralization leading to cavity formation. It was suggested that the effect of low salivary $\mathrm{pH}$ is more in plaque close to the area of susceptible tooth surface [9].

Calcium in saliva acts as the primary mineral to prevent tooth decay by its constant and continuous solubility and supply to affected areas of teeth acidogenic dissolution. All the inorganic minerals present in serum are in continuous exchange phase with saliva around dental plaque and acting as a reservoir of calcium to maintain adequate saturation level [9].
Pre-school age is an age with a high caries level in the primary teeth, which shows rapid changes over a shorter period than permanent teeth. According to WHO in the Oral Health Survey Basic Methods, one of the recommended age groups for population surveys is pre-schoolaged children which are five years old children, where the examination was carried out at the time between their fifth and sixth birthdays. The time birthdays calculation based on WHO oral health survey [10].

Amanah Kindergarten is located in a residential neighbourhood with high socioeconomic standards. At the same time, Ar-Royyan Kindergarten is situated in a middle socioeconomic community, and Ulul Azmi Kindergarten is located in the midst of a community with low socioeconomic standards. These differences shown different socioeconomic environment.

Descriptions above have encouraged us to examine the salivary $\mathrm{pH}$, feature, and volume of three pre-school-aged community. Thus, this study was aimed to describe the differences in salivary $\mathrm{pH}$, feature, and volume of the children in the three pre-school with different location and socioeconomics aspect.

\section{METHODS}

\section{Survey design}

The type of research was cross sectional. cross-sectional study as a snapshot of a particular group of people at a given point in time. [11]. Surveys are the collection of information from individual samples. This type of research technique allows various methods to recruit participants, collect data, and utilize various instrumentation methods [12].

\section{Sample}

Thestudypopulation was a pre-school-aged community of three kindergartens in the area of Bandung Regency, Indonesia with different located and socioeconomic environment. The inclusion criteria were pre-school-agedchildren and permitted by their parents; while 
the exclusion criteria were children who were under the treatment of medications that caused hyposalivation or hypersalivation, and did not want to be involved in the research.

The sampling method was consecutive sampling, which calculated with the formula to analyze the difference in the average unpaired data. The significance level in this study was chosen the significance level $\alpha=5 \%$ ( $\mathrm{Za}=$ $1.96)$; power test $95 \%$, and $(Z \beta=1.64)$; the magnitude of $d$ and $S$ was determined based on the standardized range, with the formula: d / $\mathrm{sd}=1$; where $\mathrm{d}=$ maximum value - minimum value, thus obtained the minimum sample of 25 . However, at the time of the research, the students of Ar-Royyan Kindergarten, which represents the middle socioeconomic kindergarten, only amounted to 23 students, which may become the limitation of this study.

The selection of schools was based on the socioeconomic level in a clustered district of Bandung Regency which was determined based on the agreement of all researchers, due to the limited funding of the study and the willingness of the school for participating in this research. Research samples that met the inclusion criteria were as much as 101 individuals.

\section{Data collection}

The saliva was collected using the unstimulated/drolling technique. Unstimulated saliva is saliva produced in the state of resting without exogenous or pharmacological stimulation, which has a small but continuous flow. Before saliva was collected, the subject was asked to gargle several times to remove the remaining food for about 3 min each time. Respondents were instructed to sit in an upright position with the head slightly bent forward in collecting saliva for the period of $5 \mathrm{~min}$.

Saliva collection into the collection cup was later performed by the drooling method for $5 \mathrm{~min}$ [13]. The salivary $\mathrm{pH}$ measurement was carried out using a pH litmus paper, the measurement of the salivary volume was performed using the salivary tubes with milliliters scale. The $\mathrm{pH}$ analysis was performed directly following the
$\mathrm{pH}$ collection in each kindergarten, and the salivary feature referred to the measurement of GC saliva product. All data were analysed using relative frequency distribution. All data obtained was analyzed the normality by the KolmogorovSmirnov test; then, the average differences was tested with the Kruskal-Wallis test.

\section{RESULTS}

The results of the study regarding the salivary $\mathrm{pH}$, feature, and volume of the preschool-aged community are described below. Table I shows that male and female respondents are almost equal, only differing by $5 \%$.

Table II shows that the salivary $\mathrm{pH}$ value was slightly higher in male respondents than female by 0.1 . The average $\mathrm{pH}$ value of all preschool-aged respondents was 7.25.

Table III shows that the salivary feature was found the most as slightly thick, followed by normal thin, then the thick feature was found to be the least.

Table IV shows that the salivary volume in the pre-school-aged community was found mostly in the very less category, then followed by the less category, with no normal category was found.

Normality test of salivary $\mathrm{pH}$ using Kolmogorov-Smirnov results showed that the p-value was below 0.05; thus, all the data were not normally distributed. The results of the normality test were followed by the average difference test between the two groups, which was carried out using the Kruskal Wallis test.

The mean rank values described in Table VII show that the salivary $\mathrm{pH}$ in children of high socioeconomic standard kindergarten was higher than lower socioeconomic standard and middle socioeconomic standard kindergartens. The salivary $\mathrm{pH}$ was also found to be lower than the salivary $\mathrm{pH}$ in other kindergarten students. Thin salivary features were found in high socioeconomic standard kindergarten students, followed by middle socioeconomic standard kindergarten, and most dense in the lower 
socioeconomic standard kindergarten students. Salivary volume in high socioeconomic standard children was higher than lower socioeconomic standard and middle socioeconomic standard kindergartens, with lower salivary $\mathrm{pH}$.

Table VII shows the p-values of salivary $\mathrm{pH}$ and salivary features were below 0.05 . Therefore, no significant differences found between the salivary $\mathrm{pH}$ and salivary features in children of the three kindergartens. However, there was a significant difference in the salivary volume of the children in the three kindergartens, where the kindergarten located at the high socioeconomic standard and middle socioeconomic standard areas were higher compared to the children from kindergarten in the lower socioeconomic standard area.

Table I - Frequency distribution of respondent's gender of the pre-school-aged children

\begin{tabular}{|c|cc|ccc|}
\hline Kindergarten & Male & $\%$ & Female & $\begin{array}{c}\text { Total } \\
\text { sample }\end{array}$ \\
\hline Lower socioeconomic standard & 45.7 & 19 & 54.3 & 35 & 0.536 \\
\hline Middle socioeconomic standard & 8 & 38.1 & 13 & 61.9 & 21 \\
\hline High socioeconomic standard & 29 & 64.4 & 16 & 35.6 & 45 \\
\hline Total & $\mathbf{5 3}$ & & $\mathbf{4 8}$ & & $\mathbf{1 0 1}$ \\
\hline$\%$ & $\mathbf{5 2 . 5}$ & $\mathbf{4 7 . 5}$ & $\mathbf{1 0 0}$ \\
\hline
\end{tabular}

Table II - Salivary pH of pre-school-aged children.

\begin{tabular}{|c|ccc|}
\hline Kindergarten & Male & Female & Average pH \\
\hline Lower socioeconomic standard & 7.3 & 7.2 & 7.25 \\
\hline Middle socioeconomic standard & 7.2 & 7 & 7.1 \\
\hline High socioeconomic standard & 7.4 & 7.4 & 7.4 \\
\hline Average pH & $\mathbf{7 . 3 0}$ & $\mathbf{7 . 2 0}$ & $\mathbf{7 . 2 5}$ \\
\hline
\end{tabular}

Table III - A salivary feature of the pre-school-aged children

\begin{tabular}{ccccccccccc}
\hline Kindergarten Normal & \% & $\begin{array}{c}\text { Quite } \\
\text { thick }\end{array}$ & \% & Thick & $\begin{array}{c}\text { Total } \\
\text { sample }\end{array}$ & $\begin{array}{c}\text { Average } \\
\text { pH }\end{array}$ \\
\hline $\begin{array}{c}\text { Lower socioeco- } \\
\text { nomic standard }\end{array}$ & 11 & 31.4 & 21 & 60 & 3 & 8.6 & 35 & 7.25 \\
\hline $\begin{array}{c}\text { Middle socioeco- } \\
\text { nomic standard }\end{array}$ & 6 & 28.6 & 12 & 57.1 & 3 & 14.3 & 21 & 7.1 \\
\hline $\begin{array}{c}\text { High socioecono- } \\
\text { mic standard }\end{array}$ & 6 & 13.3 & 36 & 80 & 3 & 6.7 & 45 & 7.4 \\
\hline Total & $\mathbf{2 3}$ & & $\mathbf{6 9}$ & $\mathbf{9}$ & & $\mathbf{1 0 1}$ & $\mathbf{7 . 2 5}$ \\
\hline$\%$ & $\mathbf{2 2 . 8}$ & $\mathbf{6 8 . 3}$ & $\mathbf{8 . 9}$ & $\mathbf{1 0 0}$ & $\mathbf{7 . 2 5}$ \\
\hline
\end{tabular}

Table IV - The salivary volume of pre-school-aged children

\begin{tabular}{|ccccccccc}
\hline Kindergarten & $\begin{array}{c}\text { Very } \\
\text { low }\end{array}$ & $\%$ & Low & $\%$ & Normal & $\%$ & $\begin{array}{c}\text { Total } \\
\text { sample }\end{array}$ \\
\hline $\begin{array}{c}\text { Lower socioeconomic } \\
\text { standard }\end{array}$ & 21 & 60 & 14 & 40 & 0 & 0 & 35 \\
$\begin{array}{c}\text { Middle socioeconomic } \\
\text { standard }\end{array}$ & 8 & 38.1 & 13 & 61.9 & $\mathrm{w}$ & 0 & 21 \\
\hline $\begin{array}{c}\text { High socioeconomic } \\
\text { standard }\end{array}$ & 45 & 100 & 0 & 16 & 0 & 0 & 45 \\
\hline Total & $\mathbf{7 4}$ & $\mathbf{2 7}$ & & $\mathbf{0}$ & & $\mathbf{1 0 1}$ \\
\hline$\%$ & $\mathbf{7 3 . 3}$ & $\mathbf{2 6 . 7}$ & $\mathbf{0 . 0}$ & $\mathbf{1 0 0}$ \\
\hline
\end{tabular}

Table V - Kolmogorov-Smirnov normality test of salivary $\mathrm{pH}$ from three kindergartens

\begin{tabular}{|c|c|c|c|c|c|}
\hline & Kindergarten & $\begin{array}{l}\text { Statistic } \\
\text { value }\end{array}$ & df & Sig & Remarks \\
\hline \multirow{4}{*}{$\begin{array}{c}\text { Salivary } \\
\text { pH }\end{array}$} & $\begin{array}{l}\text { Lower socioeconomic } \\
\text { standard }\end{array}$ & 0.207 & 35 & 0.001 & $\begin{array}{l}\text { Not normally } \\
\text { distributed }\end{array}$ \\
\hline & $\begin{array}{l}\text { Middle socioeconomic } \\
\text { standard }\end{array}$ & 0.232 & 23 & 0.002 & $\begin{array}{l}\text { Not normally } \\
\text { distributed }\end{array}$ \\
\hline & $\begin{array}{l}\text { High socioeconomic } \\
\text { standard }\end{array}$ & 0.152 & 46 & 0.010 & $\begin{array}{l}\text { Not normally } \\
\text { distributed }\end{array}$ \\
\hline & Total & & 104 & & \\
\hline \multirow{4}{*}{$\begin{array}{l}\text { Salivary } \\
\text { feature }\end{array}$} & $\begin{array}{l}\text { Lower socioeconomic } \\
\text { standard }\end{array}$ & 0.362 & 35 & 0.000 & $\begin{array}{l}\text { Not normally } \\
\text { distributed }\end{array}$ \\
\hline & $\begin{array}{l}\text { Middle socioeconomic } \\
\text { standard }\end{array}$ & 0.402 & 23 & 0.000 & $\begin{array}{l}\text { Not normally } \\
\text { distributed }\end{array}$ \\
\hline & $\begin{array}{l}\text { High socioeconomic } \\
\text { standard }\end{array}$ & 0.458 & 46 & 0.000 & $\begin{array}{l}\text { Not normally } \\
\text { distributed }\end{array}$ \\
\hline & Total & & 104 & & \\
\hline \multirow{4}{*}{$\begin{array}{l}\text { Salivary } \\
\text { volume }\end{array}$} & $\begin{array}{l}\text { Lower socioeconomic } \\
\text { standard }\end{array}$ & 0.390 & 35 & 0.000 & $\begin{array}{l}\text { Not normally } \\
\text { distributed }\end{array}$ \\
\hline & $\begin{array}{l}\text { Middle socioeconomic } \\
\text { standard }\end{array}$ & 0.402 & 23 & 0.000 & $\begin{array}{l}\text { Not normally } \\
\text { distributed }\end{array}$ \\
\hline & $\begin{array}{l}\text { High socioeconomic } \\
\text { standard }\end{array}$ & 0.458 & 46 & 0.000 & $\begin{array}{l}\text { Notnormally } \\
\text { distributed }\end{array}$ \\
\hline & Total & & 104 & & \\
\hline
\end{tabular}


Table VI - The mean rank from Kruskal Wallis test of salivary $\mathrm{pH}$ of three kindergartens

\begin{tabular}{|c|c|c|c|}
\hline & Kindergarten & Statistic value & df \\
\hline \multirow{4}{*}{$\begin{array}{c}\text { Salivary } \\
\text { pH }\end{array}$} & Lower socioeconomic standard & 35 & 50.91 \\
\hline & Middle socioeconomic standard & 23 & 42.17 \\
\hline & High socioeconomic standard & 46 & 58.87 \\
\hline & Total & & 104 \\
\hline \multirow{4}{*}{$\begin{array}{l}\text { Salivary } \\
\text { feature }\end{array}$} & Lower socioeconomic standard & 35 & 47.79 \\
\hline & Middle socioeconomic standard & 23 & 49.87 \\
\hline & High socioeconomic standard & 46 & 57.40 \\
\hline & Total & & 104 \\
\hline \multirow{4}{*}{$\begin{array}{l}\text { Salivary } \\
\text { volume }\end{array}$} & Lower socioeconomic standard & 35 & 66.30 \\
\hline & Middle socioeconomic standard & 23 & 45.50 \\
\hline & High socioeconomic standard & 46 & 45.50 \\
\hline & Total & & 104 \\
\hline
\end{tabular}

Table VII - Kruskal Wallis test of salivary $\mathrm{pH}$ from three kindergartens

\begin{tabular}{|c|cc|}
\hline & Kindergarten & df \\
\hline Salivary pH & Kruskal-Wallis H & 4.981 \\
& df & 2 \\
& Asymp.Sig. & 0.083 \\
\hline \multirow{2}{*}{ Salivary feature } & Kruskal-Wallis H & 3.839 \\
& df & 2 \\
\hline Salivary volume & Asymp.Sig. & 0.147 \\
& Kruskal-Wallis H & 31.587 \\
& df & 2 \\
& Asymp.Sig. & 0.000 \\
\hline
\end{tabular}

\section{DISCUSSION}

Table I shows that the male and female respondents were almost equal, with the difference only in 5\%. This composition is written to describe the respondent's gender frequency distribution in this study. Table II shows that the salivary $\mathrm{pH}$ was observed as slightly higher in male respondents by 0.1 than female.

Table II shows that the average salivary $\mathrm{pH}$ value of the respondents was 7.25. The value 7.25 is an alkaline $\mathrm{pH}$ condition. A nearly same result was found in the research conducted by Suratri et al. [14], which suggested that more than $75 \%$ of the $\mathrm{pH}$ level of pre-school- aged children was ranging from 6.8 to 8.0. An alkaline salivary $\mathrm{pH}$ will provide a high salivary secretion in children, thus increasing the salivary volume. One of the functions of saliva is to act as a buffer which helps neutralize the salivary $\mathrm{pH}$ after every meal. A high salivary volume will create a balanced salivary $\mathrm{pH}$ that will reduce the occurrence of demineralization [14].

The $\mathrm{pH}$ value of the non-stimulated saliva can reach the lowest value of 5.6 in the water and can be increased to 7.8 at a very high flow rate [15]. Salivary $\mathrm{pH}$ and salivary flow rate are the essential protective factors against dental caries. The normal salivary flow rate shows the optimum level of calcium saliva, which is very instrumental in supplying calcium continuously, reducing the progression velocity of demineralization and caries lesions development, and reducing the occurrence of dental caries [9]. To avoid a decreasing salivary flow rate, consumption of sweet treats must be avoided, also sticky foods that contain carbohydrates, because carbohydrates are the primary source of energy for oral bacteria which are directly involved in decreasing the salivary $\mathrm{pH}$ [14], and changes in the function of saliva will cause oral tissue damage which has a significant impact on the children's quality of life [15].

Table III shows the salivary feature of quite a thick saliva (68.3\%) which was found the most, followed by normal (22.8\%) and thick (8.9\%). These results indicated that the respondents' saliva experienced $78.2 \%$ viscosity. This result was consistent with the study conducted by AlAlimi et al. [16], which stated that thick saliva was found in $87 \%$ of khat chewers and $43 \%$ of nonchewers. That study suggested that the salivary viscosity of khat chewers was mostly frothy, which was categorized as the unhealthy salivary feature [16].

Frothy and thick saliva was considered as an unhealthy salivary feature because this kind of salivary feature will make the salivary flow rate becomes inadequate. Salivary viscosity affects the growth of oral Streptococci. Increasing salivary viscosity is detrimental for the oral 
health, especially in its role as the bacterial cleanser in the oral cavity. Increasing salivary viscosity can also be associated with increasing dental caries. Also, the salivary viscosity is significantly affected by the salivary $\mathrm{pH}$ and calcium [16].

Table IV shows the salivary volume in the pre-school-aged community was found at most in the very low category $(73.3 \%)$, followed by the low category (26.7\%), and no normal category was found (0\%). This result was found to be different from the study conducted towards normal caries-free children, where nearly 93.3\% children had normal salivary volume. The very low and low category salivary volume will lead to dental caries. This condition can occur because low salivary volume will cause accumulation of food retention. A high salivary volume will protect the teeth optimally through its component.

The average normal salivary production volume of an individual is approximately 1-1.5 liters a day. During sleep, the maximum salivary volume is $0.1 \mathrm{ml} / \mathrm{min}$, and with no stimulation, the volume is approximately 0.3 $\mathrm{ml} / \mathrm{min}$, while with stimulation, the salivary volume will increase to $4 \mathrm{ml} / \mathrm{min}$. The normal salivary volume collected in $5 \mathrm{~min}$ under the unstimulated condition is $1.5-2.5 \mathrm{ml} / \mathrm{min}$, and under the stimulated condition is $5-10 \mathrm{ml} / \mathrm{min}$ [17]. To achieve the average normal salivary volume, the children can do some activities such as chewing gum, mouth-rinsing, and using toothpaste or salivary spray [18].

Normal salivary volume is a beneficiary for oral health because saliva will act as the cleansing agent to remove debris and sugar retention from the oral cavity thus reducing the presence of acidogenic bacteria which will decrease demineralization [17]. Salivary volume affects the salivary flow rate which is very important for oral health because saliva affects caries incidence primarily by its flow rate and fluoride content. The salivary flow rate affects the high level of oral health, and protect the oral cavity from the bacterial substrate included in food and snacks [19]. The lower the salivary flow rate, the slower the cleansing process in the oral cavity, also, the lower the salivary buffer capacity, the more the bacteria attack will occur [17].

The symptoms of hyposalivation or mouth dryness can cause oral mucosa dehydration, which can occur when the secretion of saliva through the main salivary glands and/or small salivary glands decreases so that the salivary layer that covers the oral mucosa will be reduced. The causes of hyposalivation include autoimmune, medication effects or specific treatment, or the complications of xerostomia including dental caries and candidiasis. Such complication is very dangerous for the oral health of pre-school children thus pre-school children should be educated regarding curative practices for decreasing salivary volume [18].

The mean rank values presented in Table VII show that the salivary pH of Amanah Kindergarten students was higher than in Ulul Azmi Kindergarten and Ar-Royyan Integrated Islamic Kindergarten, which in the latter, the salivary $\mathrm{pH}$ was lower than other kindergartens. The thin salivary feature was found in Amanah Kindergarten students, followed by Ar-Royyan Integrated Islamic Kindergarten, and the thickest was found in Ulul Azmi Kindergarten students. Salivary volume in children of Amanah Kindergarten was higher than Ulul Azmi Kindergarten and Arroyyan Integrated Islamic Kindergarten students, with lower salivary $\mathrm{pH}$ found in the latter. Also, Table VII shows the $\mathrm{p}$-values of the salivary $\mathrm{pH}$ and features were below 0.05 . These results indicated that there were no significant differences between the salivary $\mathrm{pH}$ and salivary features in children of the three kindergartens. However, there was a significant difference in the salivary volume of the three kindergartens.

Chewing-stimulated salivary features (salivary flow rate, volume, $\mathrm{pH}$, and buffer capacity) affect each other. Salivary $\mathrm{pH}$, for example, is influenced by salivary flow rate, oral cavity microorganisms, and salivary buffer capacity [20,21]. While salivary flow rate is influenced by the degree of hydration, body 
position, exposure to light, day and night rhythm, drug use, age, sex, and psychological effects as a result of lifestyle and socioeconomic status. The salivary flow rate will affect the volume of saliva produced by an individual [22].

Previous studies conducted towards elder Mexicans with different socioeconomic status show how socioeconomic aspects influence these salivary features [23]. Elder Mexicans living in the public retirement home had lower salivary flow, which contributed to lower salivary volume. Conversely, elders living in a private retirement home in a higher socioeconomic area showed higher salivary $\mathrm{pH}$ value and buffer capacity than those in the public retirement home [23]. A study conducted by Belstrom et al. [24], which enrolling the Danish Health Examination Survey (DANHES) also suggested that the bacterial profile of saliva is influenced by socioeconomic status. Low socioeconomic respondents in the study show a higher level of caries-induced bacteria, such as Veillonella parvula, Veillonella atypica, and Streptococcus parasanguinis, which contributed to a lower salivary $\mathrm{pH}$ value [24].

In the health literature, it has been documented that the economic position of an individual in a society is generally a strong predictor of both morbidity and mortality. Generally, individuals with better socioeconomic status have better health conditions [25]. Krieger [26] introduced the concept of "biological expression of social inequality", which refers to how people biologically incorporate and express their experiences of economic and social inequality, from in utero to death, thereby manifesting social inequalities across a wide range of health aspects. Our present study addresses explicitly the socioeconomic of individual contributing impacts concerning the salivary parameters studied.

\section{CONCLUSION}

There are no differences between the salivary $\mathrm{pH}$ and salivary feature of children from the three studied kindergartens. However, there is a difference in the salivary volume found in children from kindergartens located in high socioeconomic standard and middle socioeconomic standard areas, which have a higher salivary volume than the children from kindergartens situated in areas with lower socioeconomic standard. Since the reduced salivary volume was associated to children with lower socioeconomic standard, this association can justify the higher risk for caries described in the literature.

\section{Acknowledgments}

Thanks for Universitas Padjdajran for funding this research.

\section{Funding}

This study was partially supported by Internal grant of Universitas Padjadjaran

\section{Conflict of interest}

The authors have no proprietary, financial, or other personal interest of any nature or kind in any product, service, and/or company that is presented in this article.

\section{Regulatory Statement}

This study was conducted in accordance with all the provisions of the local human subjects oversight committee guidelines and policies of: research ethic committee of Universitas Padjadjaran. The approval code for this study is: 915/UN6.C10/PN/2017.

\section{REFERENCES}

1. Lagerlof F,Oliveby A. Caries-protective factors in saliva. Adv Dent Res. 1994; 8(2):229-38. doi: 10.1177/08959374940080021601

2. Zhan L. Rebalancing the caries microbiome dysbiosis: targeted treatment and sugar alcohols. Adv Dent Res. 2018;29(1):110-6. doi:10.1177/0022034517736498

3. Dawes C. A mathematical model of salivary clearance of sugar from the oral cavity.Caries Res. 1983;17(4):321-34. doi:10.1159/000260684

4. Dawes C. Salivary clearance and its effects on oral health. In: Edgar M, Dawes C, O'Mullane D (eds.). Saliva and Oral Health. 4th ed:; London:Stephen Hancocks; 2012. p.81-96.

5. Pederson AML, Belstrom D. The role of natural salivary defences in maintaining a healthy oral microbiota. JDent. 2019;80 Suppl 1:S3-S12. doi: 10.1016/j.jdent.2018.08.010 
6. Dawes C. Estimates, from salivary analyses, of the turnover time of the oral mucosal epithelium in humans and the number of bacteria in an edentulous mouth. Arch Oral Biol. 2003;48(5):329-36. doi:101016/s0003-9969(03)00014-1

7. Curtis MA, Zenobia C, Darveau RP. The relationship of the oral microbiotia to periodontal health and disease. Cell Host Microbe. 2011;10(4):302-6. doi 10.1016/j.chom.2011.09.008

8. Hemadi AS, Huang R, Zhou Y,Zou J.Salivary proteins and microbiota as biomarkers for early childhood caries risk assessment. Int J Oral Sci. 2017;9(11): e1. doi: $10.1038 /$ ijos.2017.35

9. Jawed M, Khan RN, Shahid SM, Azhar A. Protective effects of salivary factors in dental caries in diabetic patients of Pakistan. Exp Diabetes Res. 2012; 947304. Doi: 10.1155/2012/947304

10. World Health Organization. Oral Health Surveys (Basic Methods). 5th ed. Geneva: WHO Library Cataloguing-in-Publication Data;2013.

11. Setia MS. Methodology series module 3: cross-sectional studies. Indian J Dermatol. 2016;61(3):261-4. doi:10.4103/0019-5154.182410

12. Ponto J.Understanding and evaluating survey research. J Adv Pract Oncol. 2015;6(2):168-71

13. Kasuma N. Physiology and pathology of saliva. Padang: Andalas University Press; 2015. p.22-6.

14. Suratri MAL, Jovina $T A$, Tjahja I. Effects $(\mathrm{pH})$ of saliva by dental caries occurrence in pre-school children age. Bulet Peneliti Kes. 2017;45(4):241-8. doi: 10.22435/bpk.v45i4.6247.241-248

15. Mahesh DR, Komali G, Jayanthi K, Dinesh D, Saikavitha TV. Evaluation of salivary flow rate, $\mathrm{pH}$ and buffer in pre, post \& postmenopausal women on HRT. JClin Diagn Res. 2014;8(2):233-6. doi: 10.7860/JCDR/2014/8158.4067

16. Al-Alimi KR, Razak AAA, Saub R. Salivary caries parameters: comparative study among Yemeni khat chewers and nonchewers. J Dent Sci. 2014;9(4):328-31. doi: 10.1016/j.jds.2014.04.003
17. Siagian FN. Comparison of salivary conditions (ph, buffer capacity, flow rate, and volume) in children with severe early childhood caries (s-ecc) and cariesfree age 6-24 months in Medan Johor University, North Sumatra University [minor thesis]. Medan: North Sumatra University; 2017.

18. Guggenheimer J,Moore PA. Xerostomia: etiology, recognition and treatment. J AmDent Assoc. 2003;134(1):61-9.

19. Rantonen P.Salivary flow and composition in healthy and diseased adults [minor thesis]. Helsínquia: Institute of Dentistry University of Helsinki;2003.

20. Cunha-Cruz J, Scott J, Rothen M, Mancl L, Lawhorn T,Brossel K, etal. Salivary characteristics and dental caries: evidence from general dental practices. J AmDentAssoc. 2013;144(5):e31-e40.

21. Nolte WA. Oral microbiology with basic microbiology and immunology. 4th ed Saint Louis: Mosby; 1982 pp. 287-9,304-5,309-10,336-8.

22. BarrettKE, Barman SM, Boltano S, Brooks HL Ganong's review of medical physiology.24th ed. New York: LANGE Basic Science;2012. p. 477-9.

23. Islas-Granillo H, Borges-Yanez SA, Medina-Solis CE, Galan-Vidal CA, NavarreteHernandez JJ, Escoffie-Ramirez M, et al. Salivary parameters (salivary flow, ph and buffering capacity) in stimulated saliva of Mexican elders 60 years old and older. West Indian Med J. 2014;63(7):758-65. doi:10.7727/wimj.2014.036

24. Belstrøm D, Holmstrup P,Nielsen CH, Kirkby N, Twetman S, Heitmann BL, et al. Bacterial profiles of saliva in relation to diet, lifestyle factors, and socioeconomic status. J Oral Microbiol. 2014;6:10.3402/jom.v6.23609. Published 2014 Apr 1. doi:10.3402/jom.v6.23609

25. Kawachil. Income inequality in health. In: Berkman L, Kawachil, eds. Social epidemiology. New York: Oxford University Press; 2000. pp. 76-93.

26. Krieger N. A glossary for social epidemiology. J Epidemiol Community Health. 2001; 55:693-700. doi:10.1136/jech.55.10.693

\section{Anne Agustina Suwargiani}

(Corresponding address)

Faculty of Dentistry, Department of Dental Public Health, Indonesia

Date submitted: 2019 Feb 14

Email: anne.agustina@fkg.unpad.ac.id 